Marquette University

e-Publications@Marquette

English Faculty Research and Publications

English, Department of

$1-1-2017$

\title{
Critical Reception since 1900
}

Albert J. Rivero

Marquette University, albert.rivero@marquette.edu

Published version. "Critical Reception since 1900" in Samuel Richardson in Context. Eds. Peter Sabor and Betty A. Schellenberg. Cambridge: Cambridge University Press 2017: 72-79. DOI. (c) 2017 Cambridge University Press. Used with permission. 


\title{
Critical Reception since Igoo
}

\author{
Albert J. Rivero
}

Looking back to Anna Laetitia Barbauld's edition of Richardson's correspondence (1804) in 1900, Clara Linklater Thomson declares that Barbauld's biographical sketch preceding the letters 'still forms the chief source of information concerning a writer whose importance in the development of English fiction would seem to render necessary a cheaper and more accessible biography'. Thomson draws from Barbauld's memoir, as well as unpublished letters and other contemporary sources, for the biographical information in her book; 'the critical chapters', she explains, 'are intended chiefly as a guide to those readers who are quite unacquainted with Richardson's novels'. ${ }^{.}$Thomson sounds a note heard throughout the nineteenth century, that, while Richardson is an important author, his novels are no longer read. In Samuel Richardson (1902), Austin Dobson identifies 'a feminine streak' in the author and finds the novels neglected because long-winded, not likely to appeal 'to-day, when with the headlong hurry of life, the language of literature seems to tend ... towards ... the short-cut and the snap-shot'. ${ }^{2}$ Thomson and Dobson thus inaugurate a century of scholarship that would reassert Richardson's importance by correcting and enriching the biographical and bibliographical record and giving his works the close critical attention they demand, eventually moving beyond the generally reductive nineteenth-century view of Richardson as dull printer and untutored genius; effeminate in sensibility (as opposed to the manly Fielding); and humourless, pompous, religious prig.

Important articles about or referencing Richardson appeared in the opening decades of the twentieth century: on his influence and his relations to French fiction, on English epistolary fiction before Pamela, and on the middle-class reader and the English novel. ${ }^{3}$ Brian W. Downs's Richardson (1928) and Paul Dottin's Samuel Richardson, 1689-176I, imprimeur de Londres, auteur de 'Pamela', 'Clarissa', et 'Grandison' (1931), coupled with the publication of the Shakespeare Head edition of the novels (1929), attested to Richardson's growing critical reputation. In the 1930s, Alan 
Dugald McKillop and William Merritt Sale, Jr, the two most influential Richardson critics of the first half of the twentieth century, began to publish their indispensable essays and books. In correcting factual errors and providing new information, McKillop's Samuel Richardson: Printer and Novelist (1936) became the first authoritative biographical and critical study. Supporting bibliographical descriptions of lifetime editions of Richardson's novels and other works with facsimiles of their title pages, Sale's Samuel Richardson: A Bibliographical Record of His Literary Career with Historical Notes (1936) set a high standard for bibliographers of eighteenth-century texts, as well as providing bibliographical information for future editors of the novels.

In the 1940s, T. C. Duncan Eaves, the future co-biographer of Richardson, completed his Harvard doctoral dissertation, 'Graphic Illustrations of the Principal English Novelists of the Eighteenth Century' (1944), ushering in the close critical scrutiny of such seemingly peripheral extra-textual features; his influential 'Graphic Illustration of the Novels of Samuel Richardson, 1740-1810' would appear in 1951. In 1943 McKillop attributed The Apprentice's Vade Mecum to Richardson; found real-life precedents for the mock marriage in Pamela (1947); and gave scholarly support to the old anecdote that villagers in Slough celebrated Pamela's wedding by ringing church bells (1949). In a major and influential study of 1948, F. R. Leavis excluded both Fielding and Richardson from the great tradition of English novelists, partially salvaging the latter 'as a major fact in the background of Jane Austen', echoing the well-worn cliché that Richardson, while strong in his 'analysis of emotional and moral states', is limited in his range and makes undue demands on the reader's time and attention. ${ }^{4}$

In 1950, Sale published Samuel Richardson: Master Printer, a descriptive study of books printed by Richardson, along with reproductions of his printer's ornaments, which would remain the authority on this topic until superseded by Keith Maslen's Samuel Richardson of London, Printer (200I). Several important essays appeared during the first half of the decade: Frank Kermode's 'Richardson and Fielding' (1950); McKillop's 'Epistolary Technique in Richardson's Novels' (195I); Ian Watt's 'Defoe and Richardson on Homer' (1952); Dorothy Van Ghent's 'On Clarissa Harlowe' (1953); and Christopher Hill's 'Clarissa Harlowe and her Times' (1955). In a typical all-male grouping of the period, Richardson appeared alongside Defoe, Fielding, Smollett, and Sterne in McKillop's The Early Masters of English Fiction (1956). Reducing the number of foundational eighteenthcentury novelists to Defoe, Fielding, and Richardson, Watt's The Rise of the Novel (1957) offered what remains, arguably, the most compelling account 
of Richardson's role in defining the protocols of realism for English prose fiction in the 1740 s and 1750 s. If McKillop and Sale shaped Richardson scholarship in the first half of the twentieth century, Watt, blending historical sociology with literary analysis, founded a new species of Richardsonian criticism, whose emphasis on class and gender informs our readings of the novels to this day.

In the I960s, T. C. Duncan Eaves and Ben D. Kimpel published a series of articles on topics ranging from Richardson's dealings with the publisher of Pamela (1960) and his London houses (1962) to the composition and revisions of Clarissa (1968), all leading up to the appearance of their still definitive Samuel Richardson: A Biography (197I). Leslie Fiedler (1960) claimed Richardson (with Goethe and Rousseau) as one of the sentimental 'founding fathers' of the novel, asserting that 'a continuing tradition of prose fiction did not begin until the love affair of Lovelace and Clarissa (a demythicized Don Juan and a secularized goddess of Christian love) had been imagined'. ${ }^{5}$ Fiedler has had an enormous influence, sometimes unacknowledged, on Richardson scholars who approach the novels from psychological or mythical contexts, such as Morris Golden in Richardson's Characters (1963) and Cynthia Griffin Wolff in Samuel Richardson and the Eighteenth-Century Puritan Character (1972). Though informed by a dismissive attitude towards Richardson and his novel, Bernard Kreissman's Pamela-Shamela: A Study of Burlesques, Parodies, and Adaptations of Richardson's 'Pamela' (1960) surveyed works appearing during the so-called Pamela craze. Martin C. Battestin's introduction to his Riverside edition of Shamela and Joseph Andrews (I96I) gave eloquent re-enunciation to the old opposition between manly Fielding and feminine Richardson, much to the latter's detriment, while William Park's 'Fielding and Richardson' (1966) emphasised the considerable common ground between the two authors. Robert Adams Day's Told in Letters (1966) and John Richetti's Popular Fiction before Richardson (1969) described the fictional milieu from which Richardson's novels emerged, thus providing a much needed corrective to Watt's male-centred 'rise' narrative. Ira Konigsberg's Samuel Richardson and the Dramatic Novel (1968) illustrated the novelist's use of theatre and dramatic techniques. Reaffirming Richardson's credentials as a canonical author, two critical anthologies were published in 1969. Richardson: A Collection of Critical Essays, edited by John Carroll, reprinted, among others, excerpts from works by Golden, Hill, McKillop, Van Ghent, and Watt, mentioned above. Twentieth-Century Interpretations of 'Pamela', edited by Rosemary Cowler, included material from McKillop and Watt as well as from pieces 
cited earlier in this paragraph, by Day, Fiedler, Golden, Kreissman, and Park.

In the 1970s, though interest in Pamela remained strong and Sir Charles Grandison (after the publication of Jocelyn Harris's Oxford edition in 1972) began to gain more ground, Clarissa emerged as the main focus of critical attention, beginning with Irwin Gopnik's linguistic approach in $A$ Theory of Style and Richardson's 'Clarissa' (1970) and ending with the deconstructive demolition of the heroine in William Warner's Reading 'Clarissa': The Struggles of Interpretation (1979). John Preston's two incisive chapters on the novel in The Created Self: The Reader's Role in EighteenthCentury Fiction (1970) 'gave early evidence that reader-response criticism was particularly well-suited to Richardson's works, and especially Clarissa. Important essays on the novel appeared throughout the decade, ranging from John Carroll's 'Lovelace as Tragic Hero' (1972) and Sheldon Sacks's 'Clarissa and the Tragic Traditions' (1972), to Leo Braudy's 'Penetration and Impenetrability in Clarissa' (1974) and a chapter establishing Clarissa's central place in the history of the sentimental novel in R. F. Brissenden's Virtue in Distress: Studies in the Novel of Sentiment from Richardson to Sade (1974), to Judith Wilt's provocative but ultimately unconvincing ' $\mathrm{He}$ Could Go No Farther: A Modest Proposal about Lovelace and Clarissa' (1977), suggesting that Clarissa was raped not by Lovelace but by the prostitutes in Mrs Sinclair's brothel. Several books, focusing on various aspects of Richardson's novels, also appeared during this decade: Donald L. Ball's Samuel Richardson's Theory of Fiction (1971), Mark Kinkead-Weekes's Samuel Richardson: Dramatic Novelist (1973), Elizabeth Bergen Brophy's Samuel Richardson: The Triumph of Craft (1974), and Gerald Levin's Richardson the Novelist (1978). Margaret Anne Doody's wide-ranging A Natural Passion: A Study of the Novels of Samuel Richardson (1974), its close readings informed by literary and theological contexts, introduced a powerful voice in Richardson studies.

Clarissa's rape became the focal point of three major books published in the early 1980 o. Feminist in emphasis but deploying different critical methodologies, Terry Castle's Clarissa's Cyphers (1982), Terry Eagleton's The Rape of Clarissa (1982), and Rita Goldberg's Sex and Enlightenment: Women in Richardson and Diderot (1984) agreed on the misogyny of the critical tradition on this topic. One of the consequences of feminist critical interest in Richardson in the 1970 and 1980 os was the move away from emphasising his 'feminine' sensibilities to gauging the extent of his 'feminism' - that is, whether Richardson was advocating for women's liberation from patriarchal constraints or simply reasserting the status quo, especially in light of 
what some critics have construed as his rigid (if not downright bigoted) religious views. During these years a convincing counter-narrative began to emerge - for example, in Jocelyn Harris's Samuel Richardson (1987) - in the portrayal of a more nuanced Richardson, whose religious views, rather than being retrograde and 'Puritan' (an erroneous label, given that he was an Anglican), were in tune with those of the early English feminist Mary Astell, whose arguments for women's equality were informed by her profound Christian faith. ${ }^{6}$ James Louis Fortuna's 'The Unsearchable Wisdom of God': A Study of Providence in Richardson's 'Pamela' (1980) explored a prominent theme in Pamela, of importance to all of Richardson's novels. In the wake of such comprehensive accounts as Doody's and Kinkead-Weekes's, Carol Houlihan Flynn's Samuel Richardson: A Man of Letters (1982) offered a generous overview of Richardson's career. Gerard A. Barker's Grandison's Heirs: The Paragon's Progress in the Late Eighteenth-Century Novel (1985) and Sylvia Kasey Marks's 'Sir Charles Grandison': The Compleat Conduct Book showed growing appreciation of Richardson's last novel. Michael McKeon's The Origins of the English Novel, 1600-1740 (1987), while recalibrating Watt's Marxist 'rise' narrative, yielded disappointing results in its superficial reading of Pamela, the only Richardson novel closely analysed. Richard Gordon Hannaford's Samuel Richardson: An Annotated Bibliography of Critical Studies (1980) and Sarah W. R. Smith's Samuel Richardson: A Reference Guide (1984) surveyed assessments of Richardson's work from the eighteenth century to the 1970s. Siobhán Kilfeather's 'The Rise of Richardson Criticism' expertly surveyed critical trends into the 1980 . Kilfeather's piece appeared in Samuel Richardson: Tercentenary Essays (1989), edited by Margaret Anne Doody and Peter Sabor - one of two indispensable collections of original Richardson scholarship appearing in the 1980 , the other being Samuel Richardson: Passion and Prudence (1986), edited by Valerie Grosvenor Myer. Harold Bloom's Modern Critical Views: Samuel Richardson (1987) reprinted ten essays or book excerpts, including ones from books noted above by Goldberg, Kinkead-Weekes, and Watt.

Usually regarded as a failure by critics from Barbauld to Doody, Pamela in Her Exalted Condition, Richardson's sequel to his spectacularly successful first novel, began to receive less dismissive notice in the 1980 - for example, in Terry Castle's 'The Recarnivalization of Pamela: Richardson's "Pamela," Part 2', in Masquerade and Civilization (1986) and Lois Chaber's 'From Moral Man to Godly Man: "Mr Locke" and Mr B in Part 2 of Pamela' (1988). Interest in the sequel continued into the 1990s, in influential essays by Ruth Perry, 'Colonizing the Breast: Sexuality and Maternity 
in Eighteenth-Century England' (1992); Toni Bowers, “"A Point of Conscience": Breastfeeding and Maternal Authority in Pamela 2' (1995); and Janet Aikins, 'Pamela's Use of Locke's Words' (1996).

Clarissa, however, remained at the centre of critical attention, beginning with the publication by AMS Press, in 1990, of an eight-volume reprint of the third edition of the novel (1753), introduced by Florian Stuber, thus launching the ambitious but ill-fated Clarissa Project. After a long hiatus, one of several volumes of contextual and critical materials planned for the series finally appeared: Clarissa and Her Readers: New Essays for The Clarissa Project (1999), edited by Carol Houlihan Flynn and Edward Copeland. Critical boóks on the novel continued to be published throughout the decade: Thomas O. Beebee, 'Clarissa' on the Continent: Translation and Seduction (1990); Lois E. Bueler, “Clarissa”s Plots (1994); Donnalee Frega, Speaking in Hunger: Gender, Discourse, and Consumption in 'Clarissa' (1998); and Gordon D. Fulton, Styles of Meaning and Meanings of Style in Richardson's 'Clarissa' (1999). The Annotations in Lady Bradshaigh's Copy of 'Clarissa' (1998), edited by Janine Barchas (with the collaboration of Gordon D. Fulton), gave wider circulation to the critical responses of one of Richardson's most astute contemporary readers. Tom Keymer's Richardson's 'Clarissa' and the Eighteenth-Century Reader (1992) marked a significant turn in our understanding of Richardson as epistolary novelist. Questioning the traditional assumption that 'Richardson turned to letters simply as a convention for achieving dramatic immediacy', Keymer examined 'the experience of writing' in order to argue that the novels 'are preoccupied ... by the deformations that arise from the rhetorical or performative tendencies of first-person discourse'?

Among studies spanning all the novels, two deserve special mention: Tassie Gwilliam's Samuel Richardson's Fictions of Gender (1993), a close interrogation of ideological contradictions inherent in Richardson's representations of male and female characters, and Stephanie Fysh's The Work(s) of Samuel Richardson (1997), a brief but useful review of Richardson's career as author and printer. Allen Michie's Richardson and Fielding: The Dynamics of a Critical Rivalry (1999) charted the reception history of both novelists from the eighteenth century to Ian Watt. New Essays on Samuel Richardson (1996), edited by Albert J. Rivero, featured thirteen essays analysing in depth issues regarding Richardson's biography and literary achievement. Though appearing in 200I, Passion and Virtue: Essays on the Novels of Samuel Richardson, edited by David Blewett, collected fourteen of thirty essays on Richardson's novels originally published in EighteenthCentury Fiction from 1988 to 1999. 
Critical trends from the twentieth century continue to be evident in the first decade-and-a-half of the twenty-first. Gender is still of paramount concern, as in Kathleen M. Oliver's Samuel Richardson, Dress, and Discourse (2008) and Bonnie Latimer's Making Gender; Culture, and the Self in the Fiction of Samuel Richardson (2013). The move away from regarding Richardson and Fielding as the 'founding fathers' of the English novel and seeing them instead as heirs to a rich tradition of women-centred fiction, exemplified by Aphra Behn, Delarivier Manley, Eliza Haywood, and Penelope Aubin, has by now become canonical. ${ }^{8}$ Theology remains an important context as well. In Reason and Religion in 'Clarissa': Samuel Richardson and 'The Famous Mr Norris, of Bemerton' (2009), for example, E. Derek Taylor has identified a crucial influence on Richardson's most doctrinally complex novel. Approaches to Teaching the Novels of Samuel Richardson (2006), edited by Jocelyn Harris and Lisa Zunshine, offers a good pedagogical guide; its editors' optimistic assertions notwithstanding, it is not clear that, beyond Pamela, Richardson's novels are much taught these days, certainly not to undergraduates. Nor is there any evidence that Richardson, whatever his rise in stock in the academy in the twentieth century, has fared well with common readers since the nineteenth. Richardson's prolixity continues to present difficulties, as evinced by the publication in 2010 of an abridgment of Clarissa (edited by Toni Bowers and John Richetti) by Broadview Press. With the publication of The 'Pamela' Controversy: Criticisms and Adaptations of Samuel Richardson's 'Pamela' (200I), edited by Thomas Keymer and Peter Sabor, and their coauthored monograph, 'Pamela' in the Marketplace: Literary Controversy and Print Culture in Eighteenth-Century Britain and Ireland (2005), Richardson's first novel has moved once again to the centre of critical attention. The recent publication of scholarly editions of both Pamela and its sequel (20II, 2012), along with a volume comprising the early works (2012), will no doubt influence and shape future Richardson criticism, as will the appearance of new editions of Clarissa and Sir Charles Grandison, as well as of his letters, over the next decade, in the Cambridge Edition of the Works and Correspondence of Samuel Richardson. A forthcoming wide-market edition of Pamela in Her Exalted Condition, in preparation by Broadview Press, might spur critical interest in Richardson's least known novel.

Because of the multiplicity and complexity of his texts, his formal innovations, his focus on rank, and his obsession with human sexuality, Richardson was perfectly positioned to attract attention from practitioners of the major critical trends of the twentieth century, from new critics to deconstructionists, from reader-response critics to book historians, 
from Marxists to feminists, from old to new historians, from Freudians to Jungians, from historians of pornography to historians of religion. Yet other, less text-centred critical movements have left Richardson largely untouched. There is no colonial or postcolonial Richardson, no ecological Richardson, very little on Richardson and race or empire or slavery. As his first readers recognised, Richardson derives his peculiar strength as a novelist from his unswerving gaze on the secrets of the human heart.

\section{Notes}

I Clara Linklater Thomson, Samuel Richardson: A Biographical and Critical Study (Horace Marshall; M. F. Mansfield, 1900), p. v.

2 Austin Dobson, Samuel Richardson (Macmillan, 1902), pp. 196-7.

3 See, for example, Frederick S. Boas, 'Richardson's Novels and Their Influence', Essays and Studies by Members of the English Association, 2 (1911), 37-70; R. S. Crane, 'Richardson, Warburton, and French Fiction', Modern Language Review, 17 (1922), 17-23; Helen Sard Hughes, 'English Epistolary Fiction before Pamela', in Manly Anniversary Studies in Language and Literature (University of Chicago Press, 1923), pp. 156-69; and Helen Sard Hughes, 'The Middle-Class Reader and the English Novel', Journal of English and Germanic Philology, 25 (1926), 362-78.

4 F. R. Leavis, The Great Tradition (London: Chatto \& Windus, 1948), p. 4.

5 Leslie Fiedler, Love and Death in the American Novel (New York: Criterion, I960), p. xx ('founding fathers' appears on p. 23).

6 Richardson printed the fourth edition of Astell's Some Reflections upon Marriage in 1730.

7 Keymer, Richardson's 'Clarissa', p. xvi.

8 See, for example, Ros Ballaster, Seductive Forms: Women's Amatory Fiction 1684-I740 (Clarendon Press, 1992); and William Beatty Warner, Licensing Entertainment: The Elevation of Novel Reading in Britain, I684-I750 (University of California Press, 1998). 